\title{
Epidermal growth factor receptors in the oesophagus
}

\author{
J Jankowski, S Murphy, G Coghill, A Grant, K G Wormsley, D S A Sanders, M Kerr, \\ D Hopwood
}

mean age of 55 years (range 23-77). Eight additional patients had Barrett's mucosa, five women and three men (median age 63 years (range 43-79)).

Biopsies were taken from different levels of the oesophagus $(20 \mathrm{~cm}$ and $30 \mathrm{~cm}$ from the incisors and at the gastrooesophageal junction (36-42 $\mathrm{cm})$ ). Eleven patients had biopsies taken from all three levels and another 30 had random biopsies from one level only (including eight patients with Barrett's mucosa). One of us (DH) graded all sections according to the severity of the histological changes (Jarvis criteria). ${ }^{20}$

Immediately adjacent to the sample taken for histological examination, a second sample was taken and immunohistochemically processed to show epidermal growth factor receptors. The biopsy was immediately snap frozen in the endoscopy room. Six micrometre cryostat sections were cut. Epidermal growth factor receptor detection involved the avidin biotin peroxidase complex method..$^{21}$ The epidermal growth factor receptor 'monoclonal antibody - type 1' was supplied by Oncogene Science (Manhasset, New York, USA). The monoclonal antibody to epidermal growth factor receptors is an IgG mouse variety and was diluted to $1: 50$.

Negative control sections of oesophageal mucosa, exposed to avidin biotin alone and Mab epidermal growth factor receptors alone showed no detectable staining pattern. Oesphageal squamous carcinoma was used as positive control tissue as this carcinoma expresses more epidermal growth factor receptors than any other tissue.

A computerised planimeter (Sonographics, USA) and Imagan-2 softwear (Kompira, UK) was used to determine the proportion of stained areas of squamous mucosa as a percentage of the total area of squamous mucosa by two independent observers (JJ and SM).

The biopsies from Barrett's columnar lined oesophagus were graded for dysplasia (Riddell criteria). ${ }^{22} 23$ The epidermal growth factor receptor content of the Barrett's mucosa was assessed by the method described by Koretz. ${ }^{2+}$

We utilised the techniques of flow cytometry in an attempt to correlate the density of cell membrane epidermal growth factor receptor expression with cell size. Five patients each had six biopsies removed from the squamous oesophagus and incubated overnight in $1 \%$ trypsin in phosphate buffered saline at $4^{\circ} \mathrm{C}$. The cells were then agitated for one minute by repeated suction into a narrow bore pipette. Cells were labelled with epidermal growth factor receptor antibody at 1/100 dilution for 30 minutes at room temperature. They were washed in phosphate buffered solution and labelled with fluorinated 


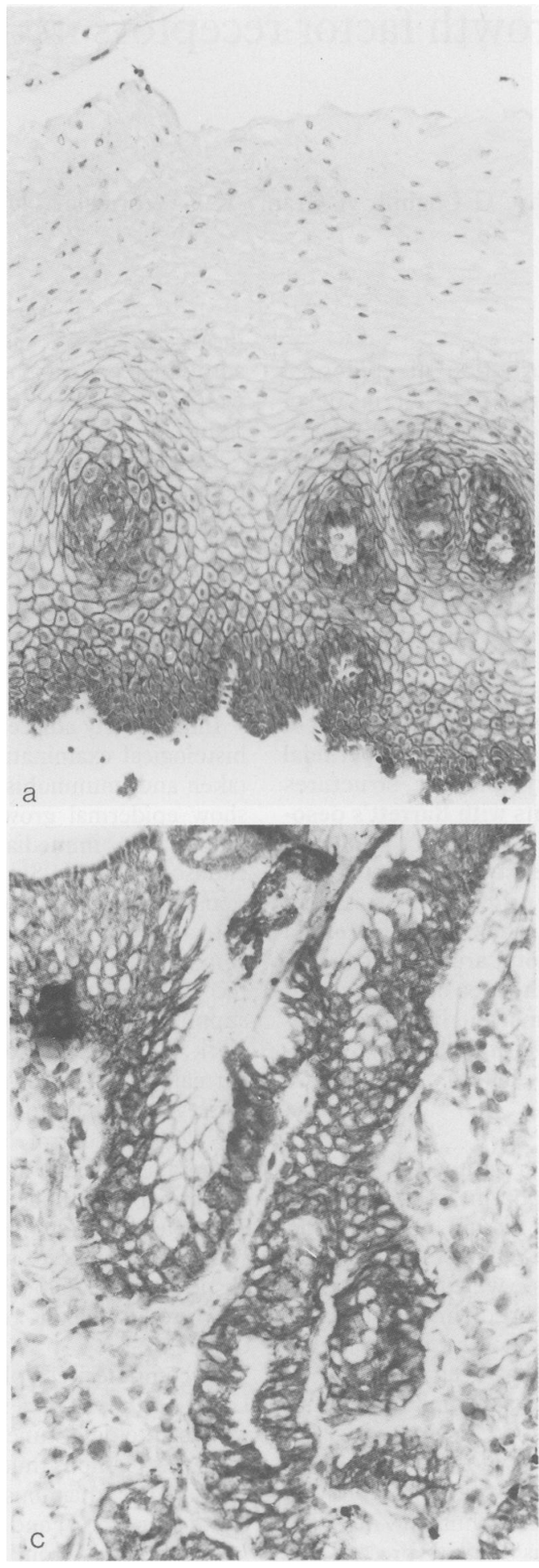

mouse secondary antibody at 1/500 dilution for 20 minutes at room temperature. Cells were fixed in $2 \%$ paraformaldehyde. A Becton-Dickinson FACSCAN flow cytometer was used to assess the relative epidermal growth factor receptor fluorescence as function of cell volume. Ten thousand labelled cells were counted from each patient. The 'consort-30' program was used to assess fluorescence and the 'LYSYS' program used to calculate the statistics (both Beckton-Dickinson softwear).

STATISTICAL ANALYSIS

Analysis of variance was used to assess the significance of the distribution of values between

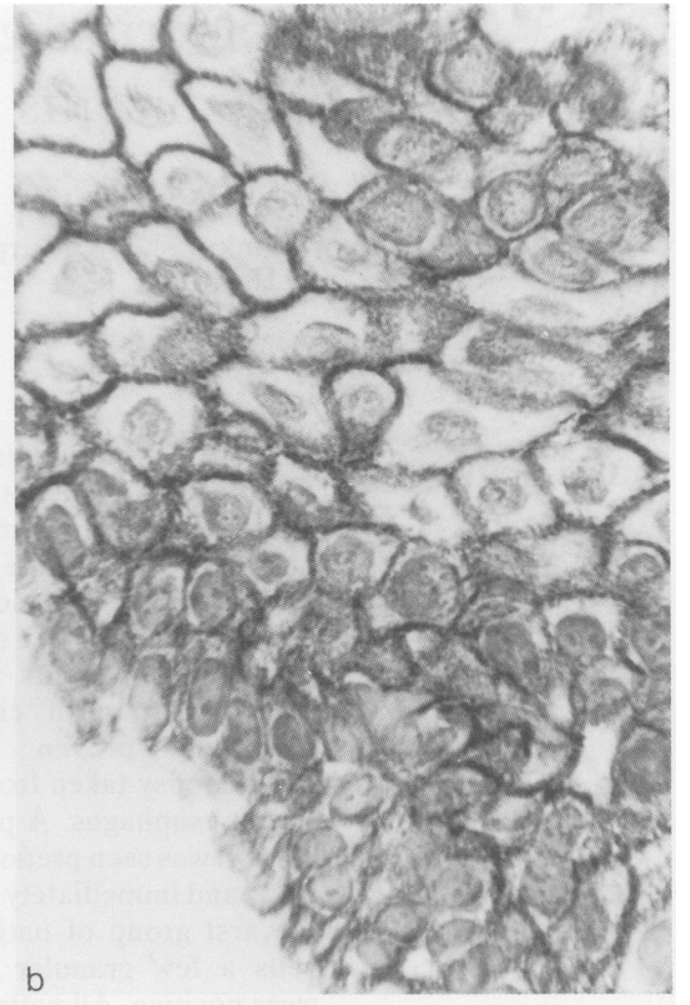

Figure 1: (a) Normal oesophageal tissue showing epidermal growth factor receptor immunohistochemical staining. (b) Normal oesophageal tissue showing intracellular epidermal growth factor receptor particulate staining. (c) Positive epidermal growth factor receptor

immunohistochemistry in a section with Barrett's mucosa.

the groups and within the groups. All values were assessed to $95 \%$ confidence intervals.

\section{Results}

\section{HISTOLOGICAL APPEARANCES}

Thirty two sections were reported as normal and 23 as showing inflammation of the squamous mucosa. Eight patients had well differentiated columnar lined oesophageal mucosa. Six being of the cardiac type and two of the intestinal type. ${ }^{23}$

\section{DISTRIBUTION OF EPIDERMAL GROWTH FACTOR} RECEPTOR

Figure la shows the pattern of distribution of epidermal growth factor receptors in oesophageal squamous cell membranes. Staining is strongly positive in the basal cell compartment and decreases in amount through the prickle cell layer and in the prolongations around the papillae, being absent from the cell membranes in the upper functional or superficial cells (Fig 1a). This membranous' staining pattern was completely circumferential involving the basolateral and apical cell surfaces. There is focal particulate epidermal growth factor receptor positivity in some of the prickle and superficial cells, possibly in lysosomes or other intracellular bodies. At higher magnification some small epidermal growth factor receptor positive bodies were noted in the cytoplasm of the basal and prickle cell compartments. These may represent organelles involved in the synthesis and packag- 


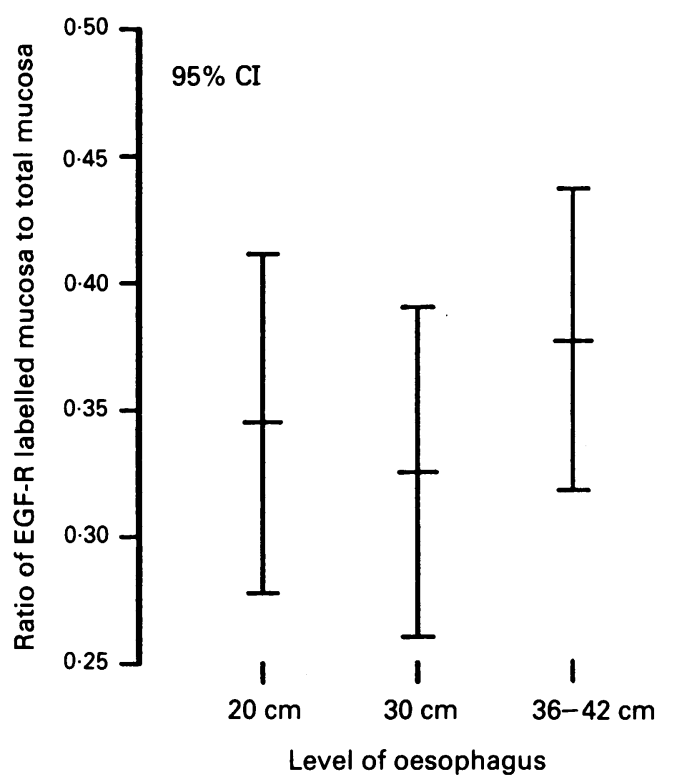

Figure 2: Epidermal growth factor receptor immunohistochemistry at different levels of normal oesophagus.

ing of the receptor (Fig lb). Only occasional cells in the lamina propria and its papillary extensions were positive for epidermal growth factor receptor.

EPIDERMAL GROWTH FACTOR RECEPTOR STAINING AT DIFFERENT LEVELS OF THE OESOPHAGUS In normal mucosa there were 11 biopsies from $20 \mathrm{~cm} ; 11$ from $30 \mathrm{~cm}$; and 11 from the gastrooesophageal junction. Figure 2 graphically illustrates that the mean epidermal growth factor receptor counts and the $95 \%$ confidence intervals at different oesophageal levels overlap in normal individuals.

EPIDERMAL GROWTH FACTOR RECEPTOR STAINING IN OESOPHAGITIS

The proportion of positively stained oesophageal epithelium was significantly greater in inflamed mucosa compared with normal uninflamed mucosa, staining positively $43 \%$ of the total area of inflamed squamous mucosa compared with a normal value of $29 \%$ (Fig 3 ).

The separation between normal oesophageal mucosa and inflamed oesophageal mucosa by planimetry was highly significant $(\mathrm{p}<0 \cdot 001)$.

There was positive staining of superficial epithelial cells in glandular areas of all sections of the columnar lined mucosa (Fig lc). The staining is mainly membranous in nature and present on apical and basolateral surfaces although there is also intracytoplasmic speckling.

\section{FLOW CYTOMETRY RESULTS}

In all five patients analysis by flow cytometry showed that there was no statistical difference between the fluorescence of the larger squames compared with the smaller squames $(p=0.4)$ (Fig 4). This finding indicates that both the larger superficial cells have a similar number of epidermal growth factor receptors expressed on the cell membrane as the smaller basal cells.

\section{Discussion}

The epidermal growth factor receptor is a glycoprotein which has ligand dependent tyrosine kinase activity. ${ }^{4}$ The $\mathrm{N}$-terminal has $\mathrm{N}$-linked oligosaccharide chains which may confer species specific differences in ligand binding. ${ }^{25-29}$ Epidermal growth receptor type-1 monoclonal antibody has been shown to bind to the 14 amino acids from Ala-351 to Asp-364 of the mature human epidermal growth factor receptor. ${ }^{30}$ In addition, there are 16 other monoclonal antibodies which bind to different epitopes on the epidermal growth factor receptor. ${ }^{30}$

The oesophageal squames normally have 20000 to 200000 epidermal growth factor receptors per cell ${ }^{29}$ and when squamous carcinoma develops this is associated with even greater expression of epidermal growth factor receptors. ${ }^{11}$ It has been suggested previously that all receptors can be demonstrated by immunohistochemistry (both high and low affinity receptors). ${ }^{\text {is }}$

The present immunohistochemical study shows that normal oesophageal mucosa has epidermal growth factor receptors in the basal and prickle cell layers, on the cell membranes, giving a 'chicken-wire' appearance in sections. This pattern of staining has been described previously by Ozawa et al." The more mature superficial epithelial cells are minimally stained immunohistochemically although there are a few immunostaining particulate bodies in the cytoplasm of these cells which probably represent lysosomes containing epidermal growth factor bound to its receptor. ${ }^{24}$ This pattern of expression of epidermal growth factor receptors is uniform, irrespective of site in the oesophagus.

Flow cytometry has indicated that the superficial epithelial cells have just as many epidermal

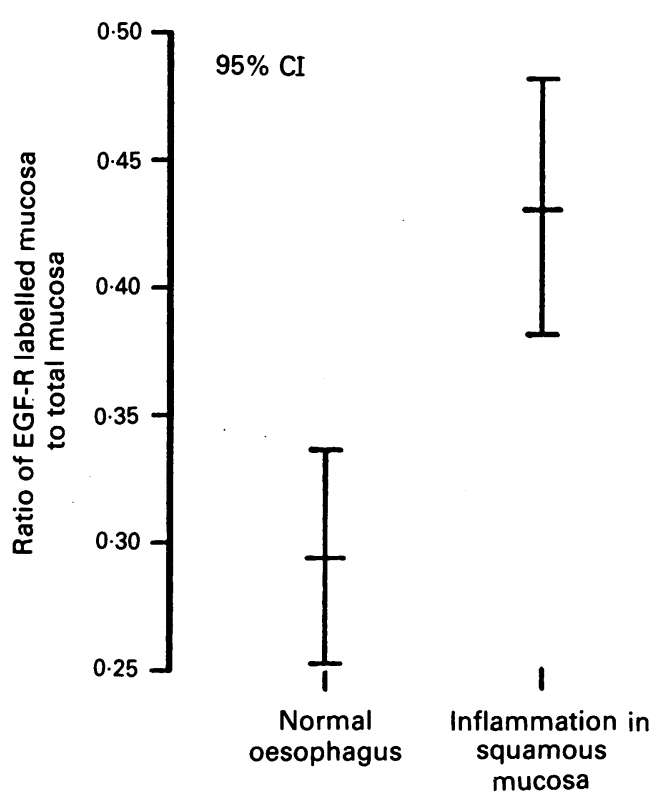

Figure 3: Epidermal growth factor receptor immunohistochemistry in normal and inflamed oesophageal tissue. 


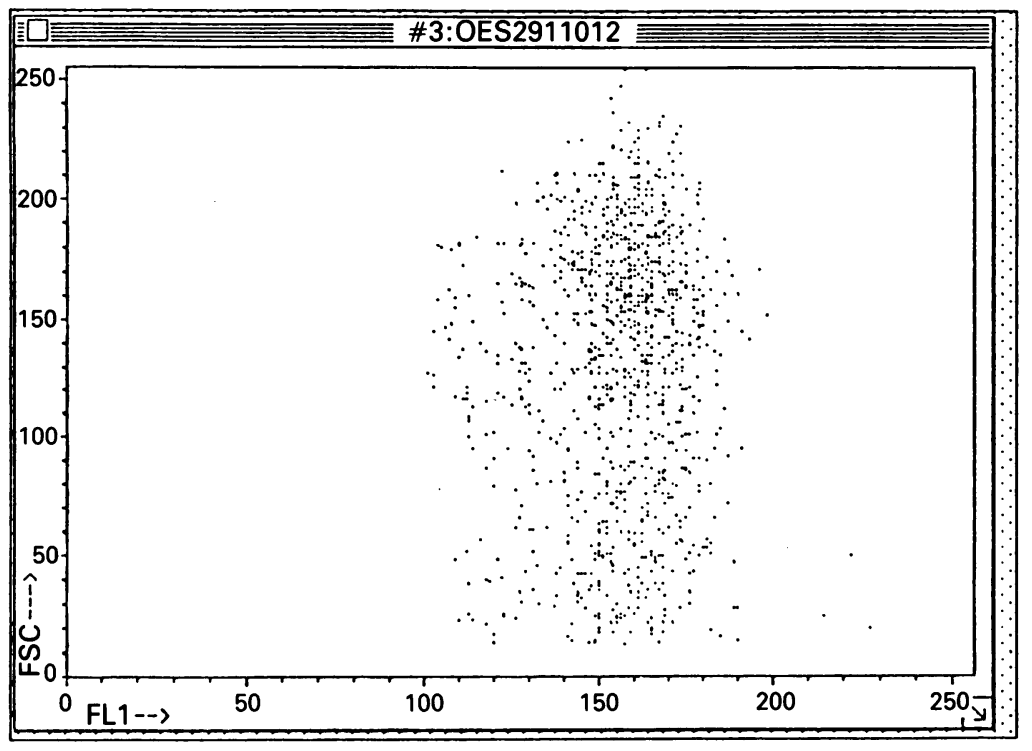

Figure 4: Scattergram of epidermal growth factor receptor expression on 10000 oesophageal squamous cells. $x$-axis fluorescence per cell, $y$-axis cell size.

growth factor receptors per cell as smaller cells. The discrepancy between the results of flow cytometric measurements and histological staining for epidermal growth factor receptors expression in the superficial layers merely reflects the greater sensitivity of laser aided fluoroscopy (flow cytometry) compared with light microscopical methods of immunohistochemistry. ${ }^{31}$ It has recently been reported that the amount of binding of radiolabelled human epidermal growth factor is similar in basal and superficial cells in the oesophagus. ${ }^{32}$ The higher density of receptors on the surface of the basal cells, however, ${ }^{11}{ }^{32}{ }^{33}$ not only explains the immunohistochemical findings but also possibly explains, in part, the greater mitotic activity of basal cells. Dimerisation of receptors is important in determining the magnitude of the subsequent intracellular actions of epidermal growth factor after binding of the ligand. Cells without a dense distribution of membrane receptors may have less epidermal growth factor induced dimerisation and therefore experience less of the subsequent intracellular actions of the peptide. ${ }^{34}$

We have recently shown that epidermal growth factor may also be found in the capillary endothelium of the submucosa, immediately adjacent to the cells with dense epidermal growth factor receptor expression. ${ }^{35}$ It seems possible, therefore, that the normal oesophageal mucosal basal layer has greater proliferative activity because it has maximal epidermal growth factor receptor density and a rich nearby source of epidermal growth factor. Our study indicates that inflamed oesophageal mucosa has significantly greater density of epidermal growth factor receptor expression than normal mucosa, a finding perhaps related to the fact that cellular proliferation is increased in oesophagitis. ${ }^{36}$ Positive epidermal growth factor receptor staining is also present in many epithelial cells from the well differentiated columnar lined (Barrett's) oesophagus, a finding which may be significant because epidermal growth factor receptor expression may be associated with cancer and oncogenesis. In this connection, we have recently reported the increased expression of epidermal growth factor receptors in intestinal type Barrett's mucosa and adenocarcinoma arising in Barrett's mucosa. ${ }^{37}$ In addition, production of abnormally great amounts of epidermal growth factor receptors has been shown in many squamous cell carcinomas, including those of the oesophagus, ${ }^{11}$ and buccal cavity. ${ }^{12}{ }^{13}$ In cancers of tissues such as breast and bladder, increased epidermal growth factor receptor levels have significant prognostic correlation with the pathological characteristics, such as tumour invasion. ${ }^{15-17}$ Whether this is also true for oesophageal carcinomas is not yet clear. ${ }^{11}$ It has been reported, however, that the squamous cells of oesophageal cancer expresses more epidermal growth factor receptor than any other tumour in vivo. ${ }^{18}$

The evidence for epidermal growth factor receptor related oncogenesis in various tumours is presented in reports showing that a ligand independent mutant of epidermal growth factor receptor derived from the oncogene c-erbB has been associated with the formation of transformed epithelial cells ${ }^{39+0}$ and also that many squamous cell carcinomas ${ }^{11121+11}$ and adenocarcinomas, including a case of Barrett's carcinoma overexpress the epidermal growth factor receptor gene. ${ }^{3++2+4}$ In addition, some carcinomas have a poorer prognosis and/or a greater chance of recurrence if they are epidermal growth factor receptor positive. ${ }^{15} 16+5$

It seems possible that epidermal growth factor receptors represent a histological marker of the increased cell proliferation in the oesophagus, which results from gastrooesophageal reflux..$^{+6+7}$ The stimulus to increased cell proliferation provided by refluxed gastric contents may act through epidermal growth factor receptor gene amplification or increased epidermal growth factor receptor gene transcription, ${ }^{6+8}$ while in Barrett's mucosa, epidermal growth factor receptor expression may represent activation of a proto-oncogene, so that subsequent gene mutations or deletions could result in neoplastic growth. ${ }^{+9}$ It is also possible that coexpression of epidermal growth factor receptor with the ligands transforming growth factor-alpha and/or epidermal growth factor stimulate other oncogenes such as c-fos and c-myc as has been shown in other gastrointestinal tumours. ${ }^{50-52}$

This present study has shown that epidermal growth factor receptor staining may be a useful adjunct to histological examination in the diagnosis of oesophagitis. Further studies are underway to assess the prognostic value in Barrett's oesophagus.

We would like to thank Mr Ronald Fawkes for production of the photographs. We are also indebted to Dr Ian Cree for his help and guidance in the use of the planimeter. (The purchase of which was
made possible by a grant from the Scottish Home and Health Department.)

1 Read AE. Whatever happened to Urogastrone? QF Med 1987; 62: 1-6.

2 Buhrow SA, Cohen S, Staros JV. Affinity labeling of the protein kinase associated with epidermal growth factor receptor in membrane vesicles. $\mathcal{f}$ Biol Chem 1982; 257 . 4019-22.

3 Pfeiffer A, Rothbauer E, Wiebecke B, Pratschke E, Kramling $\mathrm{H}$, Mann K. Increased epidermal growth factor receptors in gastric carcinomas. Gastroenterologv 1990; 98: 961-7. 
4 Velu TJ. Structure, function and transforming potential of the epidermal growth factor receptor. Mol Cell Endocrinol 1990; 70: $205-16$

5 Sporn MB, Roberts A. The epidermal growth factor family. In: Sporn MB and Roberts AN. Peptide growth factors and their receptors I. Berlin: Springer-Verlag, 1990: 100-367.

6 Hall A. Oncogenes. In: Cooper CS, Grover PL, eds. Chemical carcinogenesis and mutagenesis II. Berlin: Springer-Verlag,

7 Yoshida K, Kyo E, Tsuda T, Tsujino T, Ito $M$, Niimoto $M$, et al. EGF and TGF alpha, the ligands of hyperproduced RGFR in human esophageal carcinoma cells, act as autocrine growth factors. Int $\mathcal{F}$ Cancer 1990; 45: 131-5.

8 Tahara $\mathrm{E}$. Growth factors and oncogenes in human gastrointestinal cancer. F Cancer Res Clin Oncol 1990; 116: 121-31.

9 Lee DC, Han KM. Expression of growth factors and their receptors in development. In: Sporn $M E$, Roberts $A B$, eds. Peptide growth factors and their receptors. Berlin: SpringerVerlag, 1990: 611-703.

10 Nanney L, Stoscheck C, Magid M, King L. Altered [125I] epidermal growth factor binding and receptor distribution in psoriasis. I Invest Dermatol 1986; 86: 260-5.

11 Ozawa S, Ueda M, Ando N, Abe N, Shimizu N. High incidence of EGF receptor hyperproduction in oesophageal squamous-cell carcinomas. Int $\mathcal{f}$ Cancer 1987; 39: 333-7.

12 Partridge M, Gullick WJ, Langdon JD, Sherriff $M$. Expression of epidermal growth factor receptor on oral squamous cell carcinoma. Brf Oral Maxillofacial Surg 1988; 26: 381-9.

13 Sakai H, Kawano K, Hashimoto N. Immunohistochemical localisation of c-myc oncogene product and EGF receptor in oral squamous carcinoma. F Oral Pathol 1990; 19: 1-4.

14 Weichselbaum RR, Dunphy EJ, Beckett MA, Tybor AG, Moran WJ, Goldman ME, et al. Epidermal growth factor receptor gene amplification in head and neck lines. Head Neck 1989; ??: 437-42.

15 Messing EM. Clinical implications of the expression of epidermal growth factor receptors in human transitional cell carcinoma. Cancer Res 1990; 50: 2530-7.

16 Foekens JA, Portengen H, van Putten WLJ, Trapman AMAC, Reubi JC, Alexieva-Figusch J, et al. Prognostic value of the receptors for insulin-like growth factor 1 , somatostatin, and epidermal growth factor in human breast cancer. Cancer Res 1989; 49: 7002-9.

17 Barker S, Panahy C, Puddefoot JR, Goode AW, Vinson GP Epidermal growth factor receptor and oestrogen receptors in the non-malignant part of the breast. Br $\mathcal{F}$ Cancer $1989 ; 60$ : 673-7.

18 Leutz A, Graf T. Relationship between oncogenes and growth control. In: Sporn MB, Roberts AB, eds. Peptide growth factors and their receptors. Berlin: Springer-Verlag, 1990: factors and

19 King LE, Gates RE, Stscheck CM, Nanney LB. The EGF/ TGF alpha receptor in skin. F Invest Dermatol 1990; 94: 164 $70 \mathrm{~S}$.

20 Jarvis LR, Dent J, Whitehead R. Morphometric assessment of reflux oesophagitis in fibreoptic biopsy specimens. $\mathcal{F}$ Clin Pathol 1985; 38: 44-8

21 Coghill G, Swanson-Beck J, Gibbs JH, Fawkes RS. The avidin-biotin technique in immunocytochemical staining. In: Grange JM, Fox A, Morgan NL, eds. Immunological techniques in microbiology. Society for Applied Bacteriology. Technical Series 1987; 24: 87-110.

22 Riddell RH, Goldman H, Ransohoff DF, Appelman HD, Fenoglio CM, Haggitt RC, et al. Dysplasia in inflammatory bowel disease: standardised classification with provisional clinical applications. Hum Pathol 1983; 14: 931-68.

23 Hamilton SR. Adenocarcinoma in Barrett's oesophagus. In: Whitehead R. Gastrointestinal and oesophageal pathology. New York: Churchill Livingstone, 1989:683-700.

24 Koretz K, Schlag P, Moller P. Expression of epidermal growth factor receptor in normal colorectal mucosa, adenoma, and carcinoma. V Virchows Arch [A]. 1990; 416: 343-9.

25 Gooi HC, Hounsell EF, Lax I, Kris R, Liberman TA, Schlesinger TA, et al. The carbohydrate specificities of the monoclonal antibodies $29.1,455$ and $3 \mathrm{C} 1 \mathrm{~B} 12$ to the epidermal growth factor receptor. Biosci Rep 1985; 5: 83-94.

26 Parker PJ, Young S, Gullick WJ, Mayes ELV, Bennett P, Waterfield MD. Monoclonal antibodies against the human epidermal growth factor receptor from A431 cells. $\mathcal{F}$ Biol Chem 1984; 259: 9906-12.

27 Feizi T. Demonstration by monoclonal antibodies that carbohydrate structures of glycoproteins and glycolipids are oncohydrate structures of glycoproteins and glycolipids
developmental antigens. Nature $1985 ; 314: 53-7$.

28 Le Pendu J, Fredman P, Richter ND, Magnani JL, Willingham MC, Pastan I, et al. Monoclonal antibody 101 that precipitates the glycoprotein receptor for epidermal growth factor is directed against the $\mathrm{Y}$-antigen, not the $\mathrm{H}$ type 1 antigen. Carbohydr Red 1985; 141: 347-9.
29 Gullick WJ, Lemoine NR. EGF receptor antibody 29.1.1. [letter]. F Pathol 1990; 162: 275-6.

30 Wu D, Wang L, Sato GH, West KA, Harris WR, Crabb JW, et al. Human epidermal growth factor (EGF) receptor et al. Human epidermal growth factor (EGF) receptor sequence recognised by EGF competitive
bodies. 7 Biol Chem 1989; 264: 17469-75.

31 Reid BJ, Haggitt RC, Rubin CE, Rabinovitch PS. Barrett's esophagus; correlation between flow cytometry and histolgy in detection of patients at risk for adenocarcinoma. Gastroenterology 1987; 93: 1-11.

32 Meirowitz RF, Vengurlekar S, Resau J. Localisation and characterisation of epidermal growth factor receptors in human epithelium. Gastroenterology 1990; 98: A38.

33 Jankowski J, Murphy S, Coghill G, Grant A, Hopwood D, Wormsley KG. Epidermal growth factor receptors in the oesophagus [Abstract]. Gut 1990; 31: 1182 .

34 Todderud G, Carpenter G. Epidermal growth factor: the receptor and its function. Biofactors 1989; 2: 11-5.

35 Jankowski J, Tregaskis B, Coghill G, Grant A, Hopwood D, Wormsley KG. Epidermal growth factor in the oesophagus [Abstract]. Gut 1990; 31: 1191.

36 Livstone E, Sheahan, Behar J. Studies of esophageal cell proliferation in patients with reflux esophagitis. Gastroenterology 1977; 73: 1315-9.

37 Jankowski J, Mcmenemin R, Penston J, Hopwood D, Wormsley KG. Regulatory growth peptides in Barrett's mucosa. Clin Sci 1991; 81: 663-8.

38 Toi M, Nakamura T, Mukaida H, Wada T, Osaki A, Yamada $\mathrm{H}$, et al. Relationship between epidermal growth factor receptor status and various prognostic factors in human receptor status and various prognostic
breast cancer. Cancer 1990; 65: 1980-4.

39 Di Fiore PP, Segatto O, Lonardo F, Fazioli F, Pierce JH Aaronson SA. The carboxy-terminal domains of erbB-2 and epidermal growth factor receptor exert different regulatory effects on intrinsic receptor tyrosine kinase function and transforming activity. Mol Cell Biol 1990; 10: 2749-56.

40 Massoglia S, Gray A, Dull TJ, Munemitsu S, Kung H, Schlessinger J, et al. Epidermal growth factor receptor cytoplasmic domain mutations trigger ligant-independent transformation. Mol Cell Biol 1990; 10: 3048-55.

41 Lee K, Tanaka M, Shigeno C, Yamamoto I, Ohta S, Rikimaru $\mathrm{K}$., et al. Epidermal growth factor stimulates the anchorage dependent growth of human squamous cell carcinomas overexpressing its receptors. Biochem Biophys Res Commun 1990; 168: 905-11.

42 Ochiai A, Takanashi A, Takekura N, Yoshida K, Miyamori S, Harada $\mathrm{T}$, et al. Effect of human epidermal growth factor on cell growth and its receptor in human gastric carcinoma cel lines. Fpn $\mathcal{F}$ Clin Oncol 1988; 18: 15-25.

43 Steele RJC, Kelly P, Ellul B, Eremin O. Immunohistochemical detection of epidermal growth factor receptors on human colonic carcinomas. Br $\mathcal{F}$ Cancer 1990; 61: 325-6.

44 Yoshida K, Kyo E, Tsujino T, Sano T, Niimoto M, Tahara E. Expression of epidermal growth factor, transforming growth factor-alpha and their receptor genes in human gastric carcinomas: implication for autocrine growth. $\mathcal{F}$ pn $\mathcal{f}$ Cancer Res 1990; 81: 43-51.

45 Tahara E, Yasui W, Ochiai A, Yamamoto T, Hata J, Yokozak $\mathrm{H}$, et al. Interaction between epidermal growth factor and its receptor in progression of human gastric carcinomas. Prog Cancer Res Ther 1988; 35: 536-9.

46 Garewal H, Meltzer P, Trent J, Prabhala R, Sampliner R, Korc $M$. Epidermal growth factor receptor overexpression and trisomy 7 in a case of Barrett's esophagus. Dig Dis $S c i$ 1990; 35: 1115-20.

47 De Backer A, Haentjens H, Willems H. Hydrochloric acid. A trigger of cell proliferation in the esophagus of dogs. Dig Dis Sci 1985; 30: 884-90.

48 Basu A, Murthy U, Rodeck U, Herlyn M Mattes L, Das M. Presence of tumour-associated antigens in epidermal growth
factor receptors from different human carcinomas. Cancer Res 1987; 47: 2531-6.

49 Velu TJ, Berguinot L, Vass WC, Willingham MC, Merlino GT, Pastan I, et al. Epidermal growth factor-dependen transformation by a human EGF receptor proto-oncogene. Science 1990; 238: 1408-10.

50 Waterfield MD. Epidermal growth factors and related molecules. Lancet 1989; i: 1243-6.

51 Decker SJ. Epidermal growth factor and transforming growth factor-alpha induce differential processing of the epidermal growth factor receptor. Biochem Biophys Res Commun 1990 166:615-21.

52 Anklesaria P, Teixido J, Laiho M, Pierce JH, Greenberger JS, Massague J. Cell-cell adhesion mediated by binding of membrane-anchored transforming growth factor alpha to epidermal growth factor receptors promotes cell proliferation. Proc Natl Acad Sci 1990; 87: 3289-93. 